\title{
21. VOLCANIC GLASS IN SOME DSDP LEG 36 CORES ${ }^{1}$
}

\author{
D.H. Elliot and C.M. Emerick, Institute of Polar Studies and \\ Department of Geology and Mineralogy, The Ohio State University, Columbus, Ohio
}

The persistent occurrence of minor to trace amounts of volcanic glass in the coarse fraction of the sediment recovered at Site 329 prompted an attempt to recover the sand-sized glass and establish its composition. Samples from other sites were also examined, but the abundance in those cores is similarly low.

The siliceous organisms present dictated that without the use of elaborate procedures the only method of separation of the glass would be hand picking of the coarse fraction. The samples were washed and the greater than $62.5 \mu \mathrm{m}$ fraction was collected and hand picked; in the sand-size range the glass is colorless and transparent and is readily distinguished by its shard form (Figure 1).

The composition has been estimated by determination of the refractive index by interference microscopy. The equipment and technique were developed by E.G. Ehlers and C.M. Cocker of the Department of Geology and Mineralogy at the Ohio State University (Cocker, 1974). The equipment used allows the determination of the refractive index to \pm 0.005 . (It has since transpired that a similar technique has been developed independently by E.C.T. Chao [unpublished] and gives a precision of \pm 0.0002 .)

The results are compiled in Table 1 and Figure 2. All except two samples fall within the range 1.517 to 1.502 , corresponding to $\mathrm{SiO}_{2}$ percentages of about $64 \%$ to $72 \%$. One of the two exceptions has an R.I. of 1.523 $\left(\mathrm{SiO}_{2} \cong 62 \%\right)$, and the other an R.I. of $1.492\left(\mathrm{SiO}_{2} \cong\right.$ $75 \%)$. The bulk of the analyzed glass falls within the range 1.517 to 1.502 , but the composition can be inferred only approximately from the refractive index because of the natural variation in rock types as well as possible hydration of the glasses. The silica percentage range, $64 \%$ to $72 \%$, corresponds to rocks in the dacite to rhyolite compositional range.

The occurrence of volcanic glass shards in sediment on the Falkland Plateau can be attributed to direct airfall and settling through the water column, with an undeterminable amount of transport by bottom currents. The prevailing winds in the latitude of the Falkland Plateau are the westerlies, which would bring volcanic ash from the general area of southern South America and the northern part of the Antarctic Peninsula (Figure 3). Under certain conditions, which occur rather infrequently, it is possible to derive ash from the South Sandwich Islands which lie to the southeast. This seems unlikely for the majority of core samples because volcanic rocks of those islands have yielded $\mathrm{K}$-Ar ages

'IPS Contribution No. 286. no older than about 4 m.y. (Baker, 1968) and are possibly no older than 8 m.y., based on the sea-floor magnetic anomaly data (Barker, 1972a). Basalt and subordinate andesite make up about $95 \%$ of the exposed rocks with dacite and rhyolite forming the remainder; explosive activity does not appear to have been significant in the construction of the island arc (Baker, 1968).

The alternatives, then, are the northern Antarctic Peninsula and southern South America. The Tertiary, Quaternary, and Recent volcanic rocks of the northern Antarctic Peninsula occur in two general areas, the South Shetland Islands and the James Ross Island region. The Tertiary volcanic activity in the South Shetlands is rather poorly documented, however, it is probable that the upper Tertiary rocks are related to the subduction zone active from at least $20 \mathrm{~m} . \mathrm{y}$. to about 8 m.y. ago, based on the sea-floor magnetic anomalies in the Drake Passage (Barker, 1972b). The Tertiary volcanic rocks are largely basaltic andesites with only one felsic lava recorded (Hawkes, 1961a). The more recent activity at Deception, Penguin, and Bridgeman islands appears to be related to rifting in the Bransfield Strait. The volcanism is alkaline with a marked soda enrichment; compositions range from hawaiite through mugearite to trachyte (Baker, 1972) (olivine basalt to trachyte, Hawkes, 1961b). The age of inception of this period of volcanism is uncertain, however none of the rocks dated so far give prePleistocene ages (C.H. Shultz and R.J. Fleck, personal communication). The volcanism of the James Ross Island area (Nelson, 1966; Baker et al., 1973) is also mildly alkaline in character and the products consist largely of palagonite breccia and olivine basalt lava (hawaiite, Baker, 1972). These rocks have given $\mathrm{K}-\mathrm{Ar}$ dates from 4.6 m.y. to less than 1.0 m.y. (Rex, 1972), and like the active or recently active centers north of the Bransfield Strait, are probably associated with rifting. There is a general paucity of felsic lavas in the northern Antarctic Peninsula, although the lack of systematic survey and petrologic examination may partly account for their apparent absence; certainly felsic lavas cannot form a very significant part of the volcanic record.

Tertiary strata cover much of Patagonia from about $40^{\circ}$ southwards. Lower Tertiary rocks of volcanic origin are known from a number of areas: Eocene tuffs and lavas of basic and acid composition are recorded in the Lago Nahuel Huapi region (Dessanti, 1972); tuffs and tuffaceous rocks constituting the "Serie Riodacítica" crop out in northwestern Chubut Province (Lesta and Ferello, 1972) and are believed to be Eocene and equivalent to the "Serie Andesítica" in the cor- 

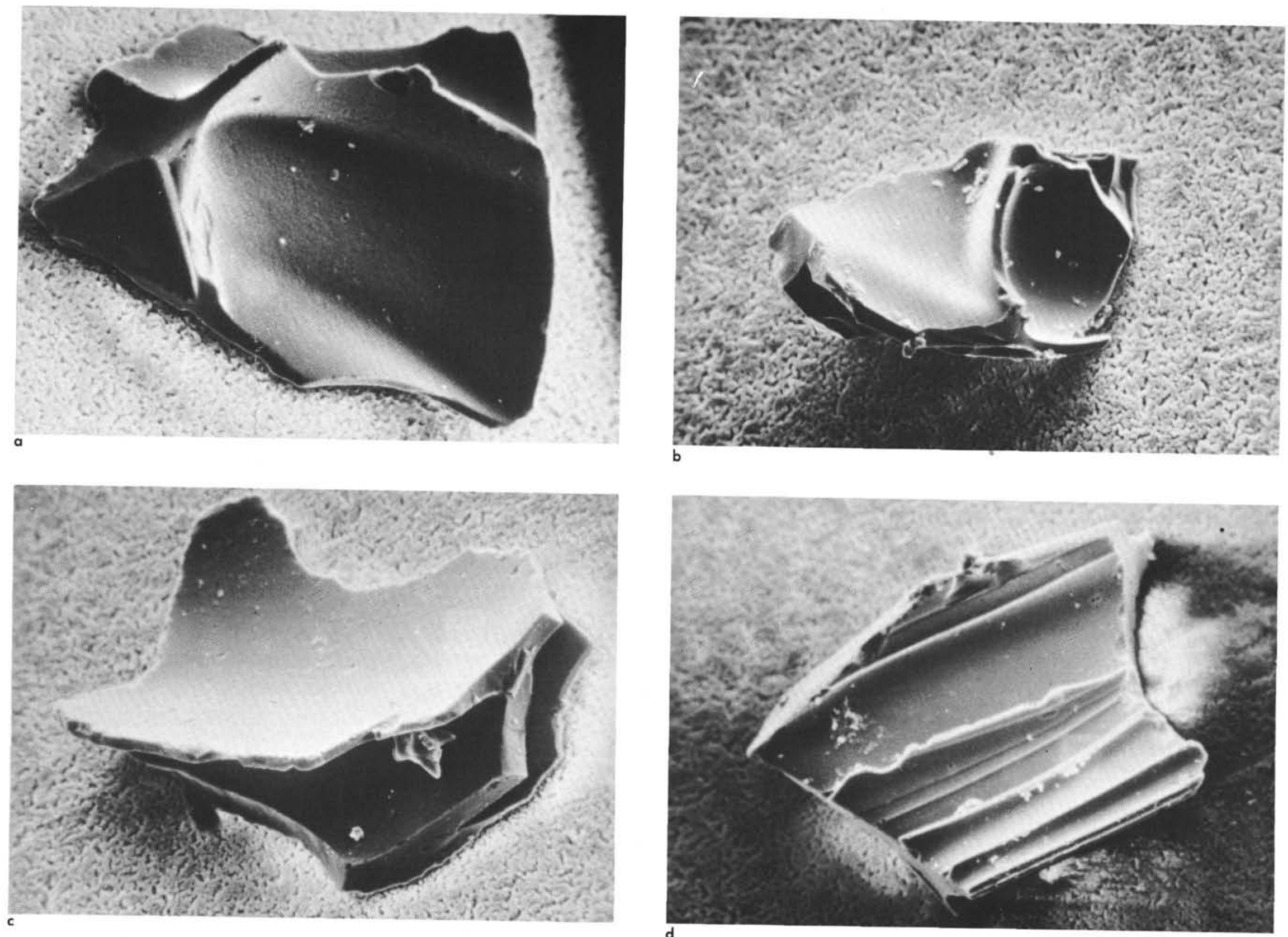

Figure 1. Scanning electron microscope photographs of volcanic glass shards from Leg cores (a) 329-3, CC; (b) 329-10, CC; (c) 329-13, CC; (d) 329-13, CC. 
TABLE 1

Refractive Index of Volcanic Glass in Some Leg 36 Core Samples

\begin{tabular}{llc}
\hline \multicolumn{1}{c}{ Sample No. } & \multicolumn{1}{c}{ Age } & R.I. \\
\hline Site 327 & & \\
$327 \mathrm{~A}-5-4,110$ & $\begin{array}{l}\text { Late Paleocene to } \\
\text { early Eocene }\end{array}$ & 1.507 \\
327A-9-1, 145 & $\begin{array}{l}\text { Late Paleocene to } \\
\text { early Eocene }\end{array}$ & 1.514 \\
\end{tabular}

Site 328

328-2, CC

328-3, CC

328A-1-1, 79-81

$328 \mathrm{~A}-1-2,54-56$

328B-1-1, 147-149

328B-2-1, 54-56

328B-2-3, 84-86

$328 \mathrm{~B}-3-4,54-56$

328B-6-2, 54-56

$\begin{array}{ll}\text { Early Pliocene } & 1.504 \\ \text { Late Miocene } & 1.505 \\ \text { Pleistocene } & 1.523 \\ \text { Pleistocene } & 1.513 \\ \text { Late Pliocene } & 1.501 \\ \text { Late Miocene } & 1.513 \\ \text { Middle Miocene } & 1.509 \\ \text { Lower Miocene } & 1.506 \\ \text { Oligocene } & 1.517\end{array}$

Site 329

329-2-3, 4-6

329-2-3, 65-67

$329-2-4,21-23$

329-2-4, 54-56

$329-2-5,54-56$

329-2-6, 54-56

$329-2, \mathrm{CC}$

329-3-1, 80-82

$329-3-4,80-82$

$329-3, \mathrm{CC}$

$329-4-1,68-70$

$329-4-5,80-82$

$329-4, \mathrm{CC}$

$329-5, \mathrm{CC}$

$329-6, \mathrm{CC}$

$329-7, \mathrm{CC}$

$329-8, \mathrm{CC}$

$329-9, \mathrm{CC}$

$329-10, \mathrm{CC}$

$329-11$, CC

$329-12, \mathrm{CC}$

$329-13, \mathrm{CC}$

$329-14$, CC

$329-19$, CC

$329-21, C C$

$329-23$, CC

$329-26$, CC

$329-27, \mathrm{CC}$

\begin{tabular}{ll} 
Late Miocene & 1.502 \\
Late Miocene & 1.504 \\
Late Miocene & 1.507 \\
Late Miocene & 1.511 \\
Late Miocene & 1.505 \\
Late Miocene & 1.516 \\
Late Miocene & 1.517 \\
Late Miocene & 1.512 \\
Late Miocene & 1.514 \\
Late Miocene & 1.516 \\
Late Miocene & 1.505 \\
Late Miocene & 1.508 \\
Late Miocene & 1.503 \\
Late Miocene & 1.510 \\
Late Miocene & 1.505 \\
Late Miocene & 1.512 \\
Late Miocene & 1.505 \\
Late Miocene & 1.509 \\
Late Miocene & 1.502 \\
Late Miocene & 1.508 \\
Late Miocene & 1.508 \\
Late Miocene & 1.513 \\
Late Miocene & 1.510 \\
Late Miocene & 1.509 \\
Middle Miocene & 1.509 \\
Middle Miocene & 1.504 \\
Middle Miocene & 1.492 \\
Middle Miocene & 1.505 \\
& \\
Oligocene to Recent & 1.512 \\
\hline
\end{tabular}

Site 330

$330 \mathrm{~A}-1-3,51-53$

dillera at least as far south as Lago Fontana and to the "Tobas de Sarmiento" in the region of the 'Gulf of San Jorge; and in northwestern Santa Cruz Province the "Serie Andesítica" crops out again and consists of intermediate to acid volcanic rocks (Leanza, 1972) although here it is assigned a ?Paleocene-Eocene age. The Patagonian Formation, which covers large areas of central and eastern Patagonia, contains both marine and nonmarine beds in which volcanic detritus in the form of tuffs and tuffaceous rocks has been observed (Feruglio, 1949). It was formerly thought to be in part Miocene, but recent work suggests it is Eocene to early Oligocene in age (Camacho, 1974). Younger Tertiary strata with a volcanic component include the Miocene Santa Cruz Formation which crops out extensively in Santa Cruz Province between the foothills of the Andes and the Atlantic Coast (Russo and Flores, 1972). The Santa Cruz Formation contains tuffs and tuffaceous sediments in which pumice fragments have been identified (Feruglio, 1949). Younger Miocene strata appear to be confined to the Collon Curá Formation; it crops out near Lago Nahuel Haupi and includes tuffs of dacite to rhyolite composition in which both volcanic glass and pumice fragments have been recognized (Dessanti, 1972). The same formational name has been applied to a sequence of rocks in the southwestern-most Santa Cruz Province which consists of conglomerate, sandstone, shale, and tuff (Leanza, 1972).

In southern South America late Cenozoic to Recent volcanic activity is concentrated along the Andes and its eastern flank in Patagonia. The Patagonian basalts are widely distributed; the thicker sequences are all adjacent to the Andes, whereas toward the Atlantic Coast the sequences are much thinner and occur irregularly. The basalts are described as alkaline and all are flood basalt sheets; no intermediate or acid compositions have been recorded. The age of the Patagonian basalts is uncertain, but is known to span at least $3.5 \mathrm{~m} . \mathrm{y}$. to 1.0 m.y. (Mercer et al., 1975). South of latitude $44^{\circ} \mathrm{S}$, where the Chile Rise abuts the South American continent, active or recently active volcanoes occur only sporadically; north of that latitude volcanoes are abundant. Information on the composition of the rocks of the southerly stratovolcanoes is sparse (Casertano, 1963; Fuenzalida, in press); andesitic compositions appear to predominate. Most of the stratovolcanoes north of the Chile Rise have been documented by Moreno (1974) and consist of a full range of calcalkaline rocks from basalt to rhyolite, although acidic compositions are subordinate.

The distribution in time of the tuffaceous strata in Patagonia and the active and recently active stratovolcanoes of the southern Andes covers the same interval as that of the core samples from the Falkland Plateau, however there is little which specifically helps correlation because of the lack of sufficient data on the age and composition of the rocks.

The source of the volcanic glass in cores examined here probably comes ultimately from the southern Andes and from explosive eruptions possibly comagmatic with the widespread Tertiary granitic plutons. Radiometric dating of plutonic rocks in the southern Andes is sparse and the only Tertiary data available is that of $12 \pm 2 \mathrm{~m} . \mathrm{y}$. for the Cerro del Paine intrusion not far north of the Straits of Magellan (Halpern, 1972).

The tentative identification of the southern Andes as the most likely source region raises some question about the magnitude of eruptions necessary to transport sand-sized material for $2-3000 \mathrm{~km}$. The factors involved in atmospheric transport of tephra have been discussed by Shaw et al. (1974), and include the magnitude of the eruption and hence the height to which the particles of any given size range are driven, and the prevailing wind velocities and hence the distance traveled 


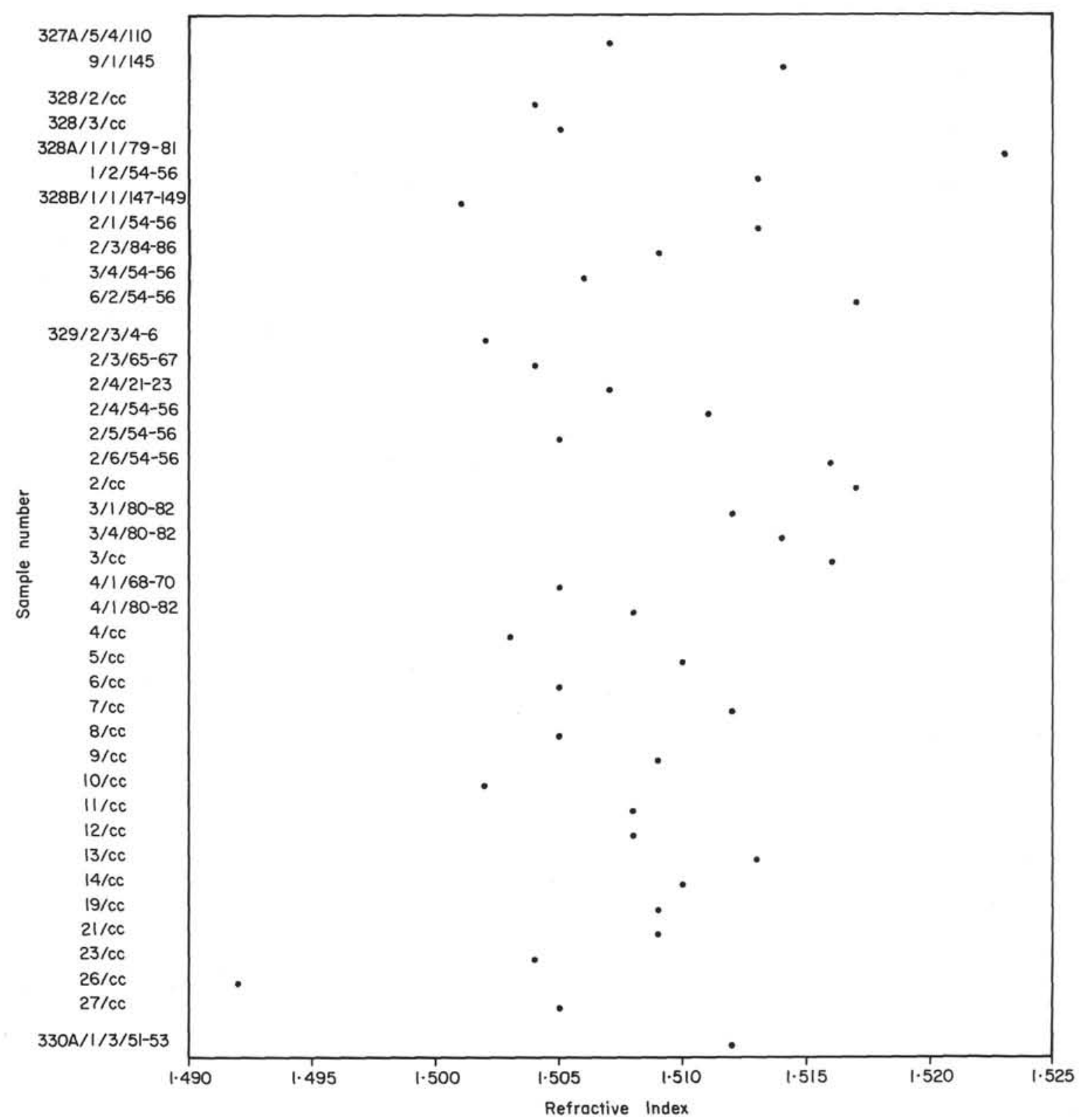

Figure 2. Refractive index of volcanic glass shards from Leg 36 cores.

by those particles before settling out. Shaw et al. (1974) discussed particles in the range 11-88 $\mu \mathrm{m}$ which includes most but not all of the size range $(>62.5 \mu \mathrm{m})$ studied in the Leg 36 cores. Using $72 \mu \mathrm{m}$ as a working grain size, it is clear from fig. 6 of Shaw et al. (1974) that for travel distances of $2-3000 \mathrm{~km}$, that eruptions of great magnitude and winds stronger than those of the North Atlantic at $50^{\circ} \mathrm{N}$ are both required. The Falkland Plateau and the southern Andes lie in the track of the prevailing westerlies of the southern midlatitudes and therefore very strong winds are to be expected. The wind velocity profile at about $50^{\circ} \mathrm{S}$, the latitude of interest here, shows that velocities may be up to one and a half times those of the equivalent latitude in the northern hemisphere (Lamb, 1972) and allows use of the theoretical models developed by Shaw et al. (1974). In this, a wind velocity one and a half times that of the North Aflantic at $50^{\circ} \mathrm{N}$ is used; if the wind velocity is not of that magnitude, the cloud height and magnitude of eruption would have to be increased accordingly. Thus the height of the cloud top, at one and a half times the wind speed, would have had to be in excess of $25 \mathrm{~km}(80,000 \mathrm{ft})$, indicating for sand-sized tephra eruptions of considerable magnitude (paleoexplosivisity of $>7$ megatons, fig. 7, Shaw et al., 1974) to travel $2000 \mathrm{~km}$ (Sites 327, 329, 330) and considerably greater magnitude to travel the extra $700 \mathrm{~km}$ to Site 328.

Assuming the results give approximately correct figures, it is clear that the source of the shards and their mode of transportation need to be re-evaluated. There is some question about the former disposition of the continental blocks around the Scotia Sea because much of the sea-floor magnetic anomaly data cannot be iden- 


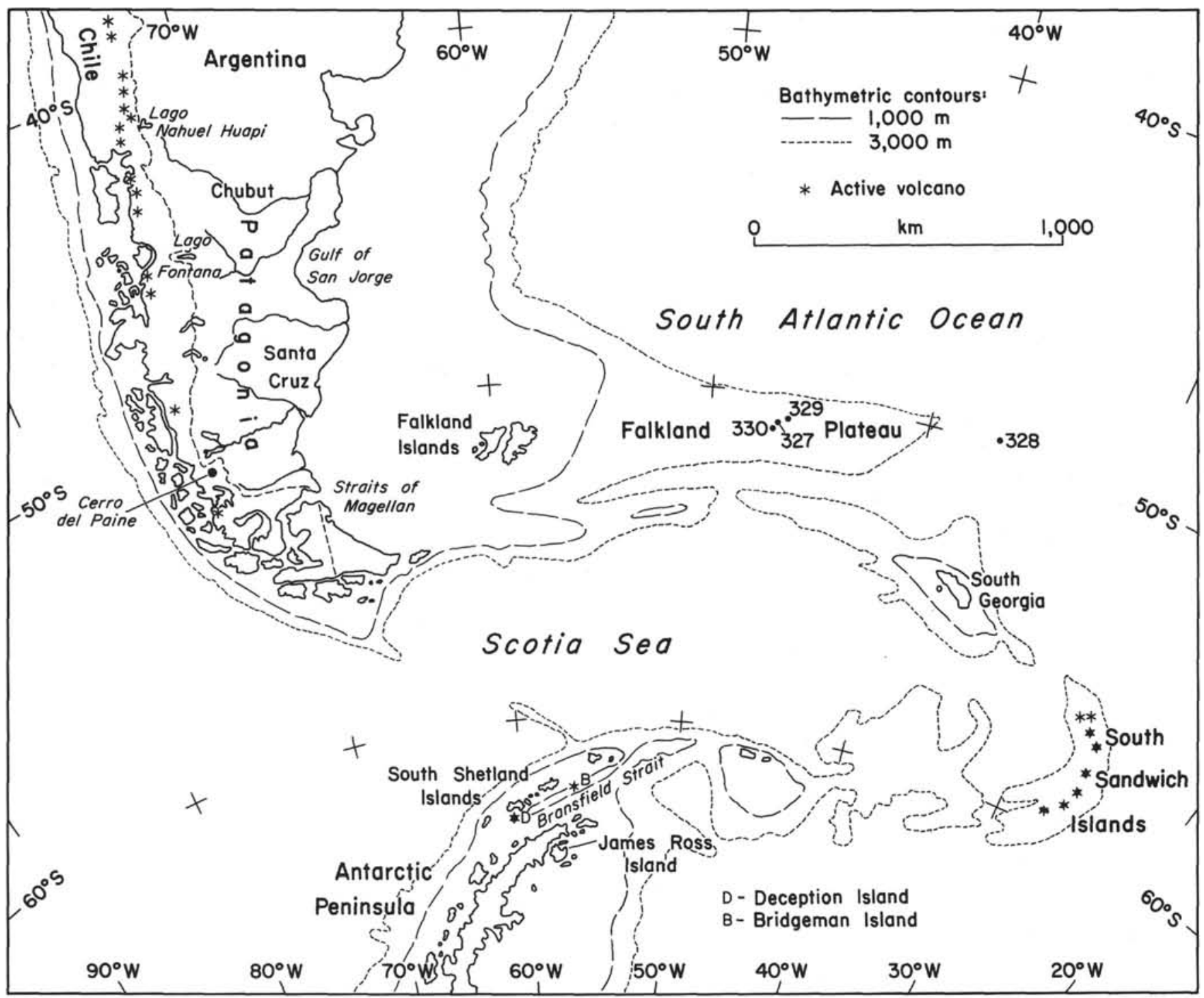

Figure 3. Location map for possible sources of volcanic glass shards from Leg 36 cores.

tified yet with the known geomagnetic polarity time scale. The South Sandwich Islands are probably no older than $8 \mathrm{~m} . \mathrm{y}$., however a precursor to that island arc may have existed although no substantial readily identifiable volcanic edifice was built. It is most unlikely to have been the source for tephra of acidic composition. The Drake Passage started to open about 20 m.y. ago, and the South Shetlands appear to contain the only associated continental volcanic record. Because events earlier in the Tertiary than that cannot be evaluated, doubts must remain about the source of the shards in older core material. However, the southern Andes appear to be the most likely source area provided oceanic currents have not displaced the sand-sized material any great distance. Bottom currents at Site 328 flow from the southeast, a direction in which there is no adequate source. Bottom currents across the Falkland Plateau flow in a northerly direction and it is possible that there has been transport from a more westerly source, however the source areas that become available, principally the Antarctic Peninsula, are again unlikely. Furthermore the prevailing westerlies would not con- sistently bring ash from the southern Andes into the Scotia Sea for subsequent transport by ocean currents.

Therefore, explosive volcanic eruptions in the southern Andes are considered to be the most likely source for the shards, and atmospheric transport the most likely mode of dispersion.

\section{ACKNOWLEDGMENTS}

We are grateful for the assistance given by C.M. Cocker with the interference microscopy and R.F. Markley with the SEM photographs. E.G. Ehlers reviewed the manuscript.

\section{REFERENCES}

Baker, P.E., 1968. Comparative volcanology and petrology of the Atlantic island arcs: Volc. Bull., v. 32, p. 189.

, 1972. Recent volcanism and magmatic variation in the Scotia Arctic. In Adie, R.J. (Ed.), Antarctic geology and geophysics: Oslo (Universitetsforlaget), p. 57-60.

Baker, P.E., González-Ferran, O., and Veraga, M., 1973. Paulet Island and the James Ross Island Volcanic Group: Brit. Antarctic Surv. Bull., v. 32, p. 89. 
Barker, P.F., 1972a. A spreading centre in the East Scotia Sea: Earth Planet. Sci. Lett., v. 15, p. 123. 1972b. Magnetic lineations in the Scotia Sea. In Adie, R.J. (Ed.), Antarctic Geology and geophysics: Oslo (Universitetsforlaget), p. 17-26.

Camacho, H., 1974. Bioestratigrafia de las formaciones marinas del Eoceno y Oligoceno de la Patagonia: Anal. Acad. Ci. Ex. Fis. Nat. Buenos Aires, v. 26, p. 39.

Casertano, L., 1963. Catalogue of the active volcanoes of the world including solfatara fields; Part XV: Chilean Continent: Internatl. Volcanol. Assoc., Naples, Italy.

Cocker, M., 1974. A new method for the determination of refractive indices using the interference microscope. MS thesis, the Ohio State University, Columbus, Ohio.

Dessanti, R.N., 1972. Andes Patagonicos Septentrionales. In Leanza, A.F. (Ed.), Geologia Regional Argentina: Córdoba, Argentina, p. 655-687.

Feruglio, E., 1949. Descripción Geológica de la Patagonia. Tomo II: Buenos Aires, Ministerio Industria y Comercio, Direccion General de Yacimientos Petroliferos Fiscales.

Fuenzalida, R., in press. The Hudson Volcano: Volc. Bull.

Halpern, M., 1972. Geologic significance of isotopic age measurements of rocks from Tierra del Fuego (Chile): Am. Geophys. Union Trans., v. 53, p. 182.

Hawkes, D.D., 1961a. The geology of the South Shetland Islands: I. The petrology of King George Island: Falkland Islands Dependencies Survey, Sci. Rept., v. 26, p. 1-28. 1961b. The geology of the South Shetland Islands: II. The geology and petrology of Deception Island: Falkland Islands Dependencies Survey, Sci. Rept., v. 27, p. 1-42.

Lamb, H.H., 1972. Climate: Present, Past and Future: London (Methuen \& Co.).
Leanza, A.F., 1972. Andes Patagonicos Australes. In Leanza, A.F. (Ed.), Geologia regional Argentina: Córdoba, Argentina, p. 689-706.

Lesta, P.J. and Ferello, R., 1972. Region Extra Andina de Chubut y norte de Santa Cruz. In Leanza, A.F. (Ed.), Geologia regional Argentina: Córdoba, Argentina, p. 601-653

Mercer, J.H., Fleck, R.J., Mankinen, E.A., and Sander, W., 1975. Southern Patagonia: Glacial events between 4 m.y. and $1 \mathrm{~m} . \mathrm{y}$. ago. In Suggate, R.P. and Cresswell, M.M. (Eds.), Quat. Stud. Roy. Soc. New Zealand Bull.: v. 13, p. 223-230.

Moreno, H., 1974. Andean volcanoes of central-south Chile: Guide book for Excursion D-3, IAVCEI Symp. on Andean and Antarctic volcanology problems, Santiago, Chile, September 1974.

Nelson, P.H.H., 1966. The James Ross Island Volcanic Group of northeast Graham Land: Brit. Antarctic Survey Sci. Rept., v. 54, p. 1-62.

Rex, D.C., 1972. Potassium-argon age determinations on volcanic and associated rocks from the Antarctic Peninsula, and Dronning Maud Land: In Adie, R.J. (Ed.), Antarctic geology and geophysics: Oslo (Universitetsforlaget), p. 133.

Russo, A. and Flores, M.A., 1972. Patagonia Austral Extra Andina. In Leanza, A.F. (Ed.), Geologia regional Argentina: Córdoba, Argentina, p. 707-725.

Shaw, D.M., Watkins, N.D., and Huang, T.C., 1974. Atmospherically transported volcanic glass in deep sea sediments: theoretical considerations: J. Geophys. Res., v. 79 , p. $3087-3094$. 